\title{
Lincoln Brower, Champion for Monarchs
}

\author{
Karen S. Oberhauser ${ }^{1 *}$, Alfonso Alonso ${ }^{2}$, Stephen B. Malcolm ${ }^{3}$, Ernest H. Williams ${ }^{4}$ and \\ Myron P. Zalucki ${ }^{5}$
}

${ }^{1}$ Arboretum, University of Wisconsin-Madison, Madison, WI, United States, ${ }^{2}$ Smithsonian Conservation Biology Institute, National Zoological Park, Washington, DC, United States, ${ }^{3}$ Department Biological Sciences, Western Michigan University, Kalamazoo, MI, United States, ${ }^{4}$ Department Biology, Hamilton College, Clinton, NY, United States, ${ }^{5}$ School of Biological Sciences, The University of Queensland, Brisbane, QLD, Australia

Keywords: Lincoln Brower, automimicry, monarch butterfly conservation, cardenolides, monarch butterfly biosphere reserve

Lincoln Pierson Brower died in Virginia, USA, on July 17, 2018 at the age of 86. Many of the authors of papers in this special volume worked directly with Lincoln, and all were influenced by his work. In particular, for the past three decades, Lincoln worked extensively with his wife Linda Fink, who helped him in field research, in discussing monarch biology, and in critiquing all his written work. Multiple eulogies to Lincoln have been published; here, we describe ways in which Lincoln influenced us as scientists and the worlds of monarch science and conservation, from early in his career until its end.

OPEN ACCESS

Edited by:

Jay E. Diffendorfer,

United States Geological Survey,

United States

Reviewed by:

Andrew K. Davis,

University of Georgia, United States

Robert Pyle,

Independent Researcher, Grays River,

WA, United States

${ }^{*}$ Correspondence:

Karen S. Oberhauser koberhauser@wisc.edu

Specialty section:

This article was submitted to

Conservation,

a section of the journal

Frontiers in Ecology and Evolution

Received: 15 January 2019

Accepted: 16 April 2019

Published: 08 May 2019

Citation:

Oberhauser KS, Alonso A,

Malcolm SB, Williams EH and Zalucki MP (2019) Lincoln Brower, Champion for Monarchs.

Front. Ecol. Evol. 7:149.

doi: 10.3389/fevo.2019.00149

\section{MONARCHS AND THE NEW FIELD OF CHEMICAL ECOLOGY}

Lincoln was a founder of the International Society of Chemical Ecology (ISCE), which promotes the understanding of interactions between organisms and their environment that are mediated by naturally-occurring chemicals (International Society of Chemical Ecology, 2019). He was also the first ISCE president, primarily due to his ground-breaking research on the chemical ecology of tritrophic interactions among milkweeds, monarch butterflies, and bird predators, illustrated eloquently by his 1969 Scientific American article on ecological chemistry (Brower, 1969).

Like many creators of iconic scientific paradigm shifts, Lincoln was a product of his moment in time. In 1914, Oxford-based evolutionary biologist Edward Poulton presciently called for North American chemists to test the hypothesis of Haase (1896) that larvae of aposematic butterfly models in Batesian mimicry systems are toxic because they sequester chemical defenses from toxic hostplants. Poulton (1914) targeted two North American butterfly-plant systems as being particularly likely to yield results, Danaus plexippus feeding on Asclepiads and Battus philenor feeding on Aristolochias.

It took another 44 years before Lincoln's first wife, Jane Van Zandt Brower, published her research on bird predation of monarchs and mimetic viceroy butterflies (Brower, 1958). This coincided with a Fulbright-funded year at Oxford University for Lincoln and Jane after their doctorates at Yale. At Oxford, the Browers worked in the ecological genetics laboratory of E.B. Ford who was developing Poulton's legacy, and also collaborated with Miriam Rothschild, the Nobel prize-winner Tadeusz Reichstein, and graduate student John Parsons to study the chemical ecology of monarch butterflies and cardenolides, a group of toxic steroids found in their milkweed hostplants.

Building on the metaphor of the "ecological theater and the evolutionary play" coined by his Yale mentor G. Evelyn Hutchinson, Lincoln published a paper on the response of bird predators to monarchs that were reared on cardenolide-rich Asclepias curassavica, or controls that were reared either on a cardenolide-free milkweed vine, Gonolobus rostratus, or cabbage leaves (with much difficulty!). With the use of the famous "barfing blue jay assay," Lincoln and his colleagues 
found that monarchs reared on A. curassavica prompted blue jays to vomit, but monarchs reared on the control host plants did not induce an emetic response (Brower et al., 1967). These differences prompted them to develop the concept of "automimicry"; monarchs that fed as larvae on milkweeds with little cardenolide are palatable automimics of model monarchs that fed as larvae on milkweeds rich in cardenolides.

Although Lincoln was mostly interested in studying how different milkweeds influenced monarch defenses against bird predators, he did follow Poulton's advice of half a century earlier and developed collaborations with North American chemists to develop ecologically meaningful cardenolide measures in milkweeds and monarchs. Thus began seminal work showing how different milkweed host plants influenced the chemical defenses of monarchs (Brower et al., 1968, 1972; Brower, 1969; Brower and Glazier, 1975). Given the important contributions of both Lincoln and Jane Van Zandt Brower to our understanding of mimicry, Pasteur (1982) suggested that automimicry be named "Browerian" mimicry, a fitting tribute to insightful research that spans ecology, evolution, behavior, physiology, and chemistry!

Lincoln's work on cardenolides also spawned research on the role that milkweeds and cardenolides play in the annual cycle of monarchs, and also helped us understand how the annual cycle operates. His collaborations with chemical ecologists generated a series of papers in which the cardenolide "fingerprints" of monarchs reared on seven Asclepias species were described from thin layer chromatography separations and spectrophotometric quantifications (Nelson et al., 1981; Brower et al., 1982, 1984a,b; Seiber et al., 1986; Lynch and Martin, 1987; Martin and Lynch, 1988; Malcolm et al., 1989; Martin et al., 1992). These cardenolide fingerprints allowed Lincoln and his colleagues to describe variation in cardenolide sequestration through the annual cycle and to show that monarchs migrate each spring through successive broods to colonize their summer breeding habitat (Malcolm and Brower, 1989; Malcolm et al., 1993; Malcolm, 1995). The work on breeding also included field experiments that showed adverse effects of host plant characters on early monarch survival and oviposition behavior (Zalucki et al., 1990, 2001a,b; Zalucki and Brower, 1992; Zalucki and Malcolm, 1999). In sum, Lincoln's work with his students and colleagues provided a robust foundation for a wide range of research on sequestration, chemical defense, host plant use, migration, and life history variation, building a foundation for the interpretation of human impacts on monarch butterflies (Malcolm, 2018).

\section{FOCUS ON MEXICO}

The publication of Urquhart's National Geographic article (Urquhart, 1976) on the discovery of the overwintering sites of monarchs in Mexico was transformative for Lincoln. Because Urquhart did not share the location of the sites, Lincoln and Bill Calvert took up the challenge to find them (described in Brower, 1995). They focused their efforts on the known locations of the endemic oyamel fir trees (Abies religiosa) shown in the article, and Calvert quickly found dense aggregations of the butterflies on a mountain in Michoacán. Soon thereafter, in January 1977,
Lincoln first viewed the awe-inspiring spectacle of millions of monarchs clustered on high elevation oyamels. He spent much of the next winter studying birds preying upon monarchs roosting on these Mexican mountains and the importance of food plant choice for chemical defenses against predators (Calvert et al., 1979; Fink and Brower, 1981). These experiences changed his career, generating an emphasis that shifted toward monarch conservation (Brower, 1995).

For the next 40 years, Lincoln worked in the Mexican overwintering sites, studying monarchs and their interactions with the forests that are their winter home. Those of us lucky enough to spend time with him there learned lessons about monarch biology and witnessed his incredible passion for these insects and their habitat. Collectively, the research conducted by Lincoln and dozens of colleagues resulted in major contributions to our understanding of the biology and conservation of monarchs in Mexico, including predation, microclimatic influences on survival, impacts of winter storms, monarch clustering behavior, and forest dynamics. He led research to demonstrate the dependence of monarchs on the forest microclimate during the overwintering season (summarized in Williams and Brower, 2015). The canopy protects clustered monarchs from night-time freezes and protects them from wetting, which lowers their resistance to low temperatures. But logging creates holes in the protective canopy and exposes overwintering monarchs to an increased likelihood of death from freezing.

Lincoln worked hard to convince national and local authorities of the need to stop logging at the overwintering sites. He described monarch migration as an endangered biological phenomenon (Brower and Pyle, 1980; Brower and Malcolm, 1991) and was instrumental in the creation of protected areas for overwintering monarchs. A 1980 presidential decree recognized the importance of the monarch overwintering phenomenon, but no area was delineated for protection. In 1986, a second presidential decree established the Special Monarch Butterfly Biosphere Reserve, protecting 16,000 ha of land in five separate locations (Brower, 1995). In 2000, the current Monarch Butterfly Biosphere Reserve was created to protect 56,000 ha, and Lincoln played a key role in helping to delineate the protected area based on monarch biology (summarized in Missrie, 2004).

\section{CONSUMMATE COLLABORATOR AND MENTOR}

As an engaged scholar, Lincoln joined and generated many discussions about science and conservation, welcomed different views from colleagues, served leadership roles in a number of professional organizations, and mentored dozens of students and younger scientists. He was generous in spirit, and throughout his career, openly and enthusiastically encouraged others to join him in research. It is no surprise, consequently, that the 167 peer-reviewed articles listed on his CV show a wide web of collaboration; they were written, entirely by coincidence, with 167 different coauthors (Figure 1). Lincoln's legacy is wide and enduring, not just through his published research but also 


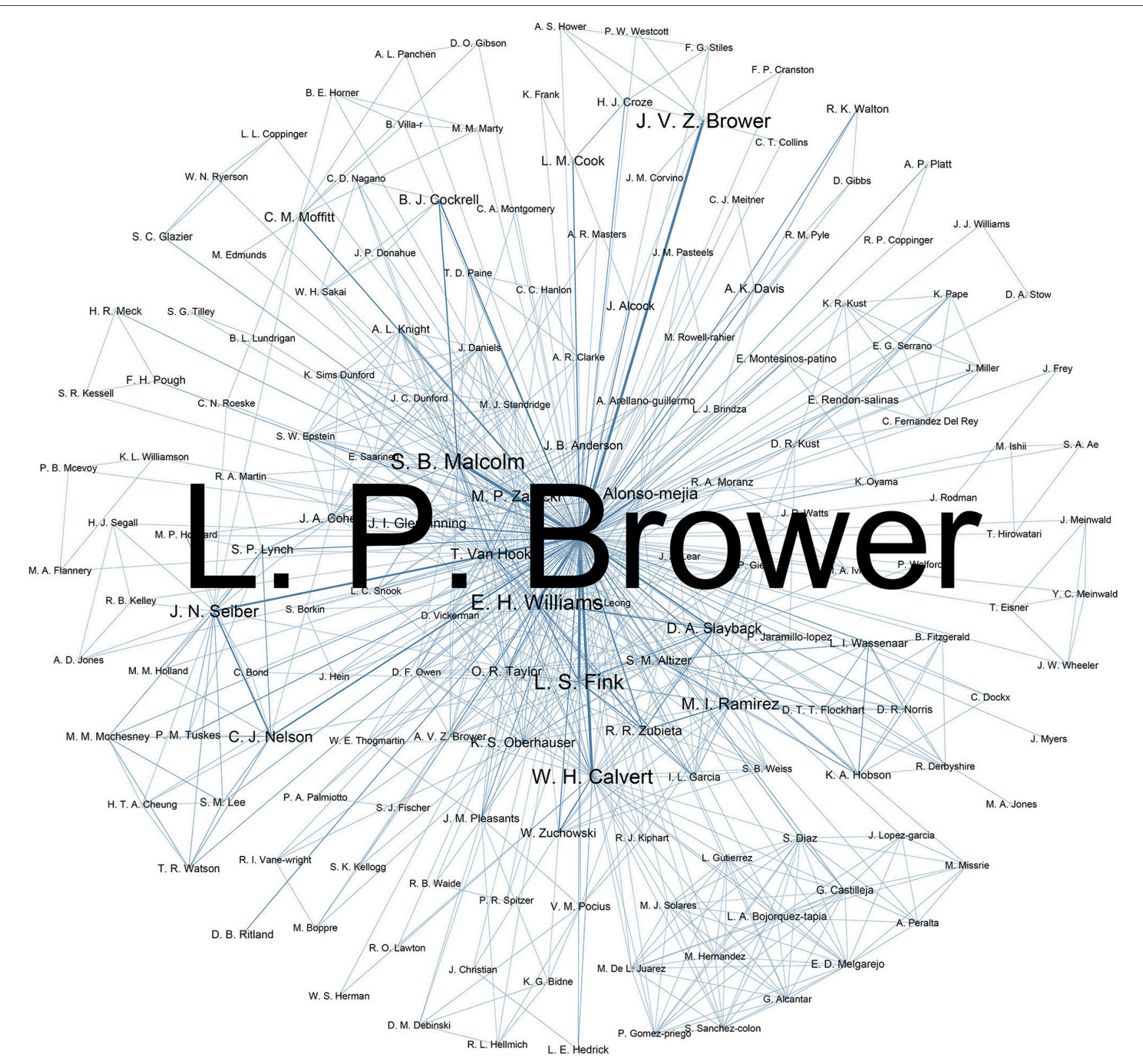

FIGURE 1 | Coauthor network of Lincoln Brower and his 167 coauthors; prepared by Mary Ellen Sloane and Reana Gibson,MTSU.

through the many people that he brought to the study and appreciation of monarchs and, more generally, all of nature.

Lincoln's natural interest and curiosity inspired students who were lucky enough to work with him, particularly during field expeditions; his influence on one of us (AA), illustrates the pivotal role that he played in many scientific careers. In the fall of 1985, Lincoln asked Dr. Jorge Soberon, a Mexican professor at the Universidad Nacional Autonoma de Mexico, to recommend two undergraduate students of biology to accompany his graduate students at the University of Florida for a research expedition he was organizing. Alfonso Alonso and Alfredo Arellano took on the opportunity, but not before debating the wisdom of skipping class for a semester to camp in the mountains of Mexico for 3 months. Their decision changed their lives forever. Lincoln came to the camp in mid-February 1986, and spent a week walking with the students all over one of the most important overwintering sites in the Sierra Chincua, in the State of Michoacán. They visited Lincoln's favorite spots and talked extensively about monarch biology and his ideas on how to conserve the forest in Mexico.

The following year, Lincoln invited Alfonso to visit his lab at the University of Florida for 3 months. Alfonso practiced English and applied to the graduate program in Zoology. Lincoln found funds to support his graduate work, and Alfonso began his $\mathrm{PhD}$ work in fall 1988. Upon his arrival in Gainesville, Lincoln literally 
took Alfonso under his wing. He taught him academic skills like scientific writing and public speaking, as well as personal traits, like generosity.

All of us feel lucky to have been mentored by Lincoln, as graduate students or post-docs, and to have watched his interest in the next generations of scientists continue as he interacted with our own students. One of us (KO) recalls a pair of her favorite memories of Lincoln, watching him interact with Middle School students she had invited to meetings in San Luis Obispo, California and Minneapolis, Minnesota. In both cases, he treated these students exactly as he would have treated a senior and esteemed colleague, and they came away from these conversations feeling that they had discovered some of the most interesting things in the world.

\section{A CHAMPION FOR NATURE}

As Lincoln built his lasting contribution to chemical ecology and to science in general, monarchs began to show signs of an uneasy relationship with humans. Once researchers started to monitor these highly mobile insects with an almost continentwide distribution, it was clear to Lincoln and many in the monarch scientific community that the numbers of monarchs reaching Mexico were declining with time and the development of profoundly different agricultural technologies across the North American landscape (Malcolm, 2018). Dramatically reduced numbers of overwintering monarchs prompted a shift in Lincoln's energies from the chemical ecology of monarchmilkweed interactions to the conservation of monarchs that navigate across landscapes dominated by human agriculture. During much of the last three decades of his career, Lincoln focused on conservation science and action (e.g., Pyle, 2019). His scientific work included both field and laboratory studies of monarch habitat requirements, especially during the winter

\section{REFERENCES}

Brower, J. V. Z. (1958). Experimental studies of mimicry in some North American butterflies. Part I. The monarch, Danaus plexippus, and viceroy, Limenitis archippus archippus. Evolution 12, 32-47.

Brower, L. P. (1969). Ecological chemistry. Sci. Am. 220, 22-29.

Brower, L. P. (1995). Understanding and misunderstanding the migration of the monarch butterfly (Nymphalidae) in North America: 1857-1995. J. Lepid. Soc. 49, 304-385.

Brower, L. P., Brower, J. V. Z., and Corvino, J. M. (1967). Plant poisons in a terrestrial food chain. Proc. Nat. Acad. Sci. U.S.A. 57, 893-898.

Brower, L. P., and Glazier, S. C. (1975). Localization of heart poisons in the monarch butterfly. Science 188, 19-25.

Brower, L. P., and Malcolm, S. B. (1991). Animal migrations: endangered phenomena. Amer. Zool. 31, 265-276.

Brower, L. P., McEvoy, P. B., Williamson, K. L., and Flannery, M. A. (1972). Variation in cardiac glycoside content of monarch butterflies from natural populations in eastern North America. Science 177, 426-429.

Brower, L. P., and Pyle, R. M. (1980). "Remarks on endangered wildlife spectacles," in 54th Meeting of the Commission, International Union of the Conservation of Nature and Natural Resources Survival Commission (Gainesville, FL), 26.

Brower, L. P., Ryerson, W. N., Coppinger, L. L., and Glazier, S. C. (1968). Ecological chemistry and the palatability spectrum. Science 161, 1349-1351.
(Williams and Brower, 2015); he worked with Mexican government and NGOs to design the current extent of the Monarch Butterfly Biosphere Reserve (Missrie, 2004); was a founding officer and board member of the Monarch Butterfly Fund until a few months before his death (Monarch Butterfly Fund, 2018); a board member of the citizen science project Journey North (Journey North, 2018); and a signatory of the petition to the USFWS as a threatened species (Center for Biological Diversity, 2014). He received accolades from the Mexican government, including the prestigious Reconocimiento a la Conservacion do la Naturaleza from the Mexican Federal Government.

Traveling with Lincoln in Mexico or through the central plains of the US was always filled with conservation lessons; he pointed out the importance of microhabitats caused by clouds over the mountains, endemic or rare flora and fauna, and amazing interactions between species and their living and non-living environment. And while he lamented the impacts of humans on these things, he was never too busy to take time to talk with kindness and respect to people from all backgrounds and knowledge levels; this compassion went a long way toward selling his conservation message. This ability to communicate so effectively and eloquently through has publications, films, and presentations is the basis of Lincoln Brower's lasting scientific legacy; we all win from his 86 years of passion dedicated to monarchs and nature.

\section{AUTHOR CONTRIBUTIONS}

KSO led the manuscript development process. KSO, AA, SBM, EHW, and MPZ contributed equally to the content. All authors benefited from their associations with Lincoln P. Brower throughout most of their careers.
Brower, L. P., Seiber, J. N., Nelson, C. J., Lynch, S. P., Hoggard, M. P., and Cohen, J. A. (1984b). Plant-determined variation in cardenolide content and thinlayer chromatography profiles of monarch butterflies, Danaus plexippus reared on milkweed plants in California 3. Asclepias californica. J. Chem. Ecol. 10, 1823-1857.

Brower, L. P., Seiber, J. N., Nelson, C. J., Lynch, S. P., and Holland, M. M. (1984a). Plant-determined variation in the cardenolide content, thin-layer chromatography profiles, and emetic potency of monarch butterflies, Danaus plexippus L. reared on milkweed plants in California: 2. Asclepias speciosa. J. Chem. Ecol. 10, 601-639.

Brower, L. P., Seiber, J. N., Nelson, C. J., Lynch, S. P., and Tuskes, P. M. (1982). Plant-determined variation in the cardenolide content, thin-layer chromatography profiles, and emetic potency of monarch butterflies, Danaus plexippus reared on the milkweed, Asclepias eriocarpa in California. J. Chem. Ecol. 8, 579-633.

Calvert, W. H., Hedrick, L. E., and Brower, L. P. (1979). Mortality of the monarch butterfly (Danaus plexippus L.) due to avian predation at five overwintering sites in Mexico. Science 204, 847-851.

Center for Biological Diversity (2014). Petition to Protect the Monarch Butterfly (Danaus plexippus plexippus) Under the Endangered Species Act. Available online at: https://www.biologicaldiversity.org/species/invertebrates/ pdfs/Monarch_ESA_Petition.pdf (accessed January, 3 2019).

Fink, L. S., and Brower, L. P. (1981). Birds can overcome the cardenolide defence of monarch butterflies. Nature 291, 67-70. 
Haase, E. (1896). Researches on Mimicry on the Basis of a Natural Classification of the Papilionidae. Part II Researches on Mimicry. Stuttgart: Nägele.

International Society of Chemical Ecology (2019). About ISCE. Available online at: https://www.chemecol.org/aboutISCE.shtml (accessed December, 31 2018).

Journey North (2018). Journey North: Tracking Migrations and Seasons. Available online at: https://journeynorth.org/ (accessed December, 31 2018).

Lynch, S. P., and Martin, R. A. (1987). Cardenolide content and thin-layer chromatography profiles of monarch butterflies, Danaus plexippus L., and their larval host-plant milkweed, Asclepias viridis Walt., in northwestern Louisiana. J. Chem. Ecol. 13, 47-70.

Malcolm, S. B. (1995). Milkweeds, monarch butterflies and the ecological significance of cardenolides. Chemoecology 5, 101-117.

Malcolm, S. B. (2018). Anthropogenic impacts on mortality and population viability of the monarch butterfly. Ann. Rev. Entomol. 63, 277-302. doi: 10.1146/annurev-ento-020117-043241

Malcolm, S. B., and Brower, L. P. (1989). Evolutionary and ecological implications of cardenolide sequestration in the monarch butterfly. Experientia 45, 284-295.

Malcolm, S. B., Cockrell, B. J., and Brower, L. P. (1989). Cardenolide fingerprint of monarch butterflies reared on the common milkweed, Asclepias syriaca L. J. Chem. Ecol. 15, 819-853.

Malcolm, S. B., Cockrell, B. J., and Brower, L. P. (1993). "Spring recolonization of eastern North America by the monarch butterfly: successive brood or single sweep migration?" in Biology and Conservation of the Monarch Butterfly, eds S. B. Malcolm and M. P. Zalucki (Los Angeles, CA: Natural History Museum of Los Angeles County, Science Series 38), 253-267.

Martin, R. A., and Lynch, S. P. (1988). Cardenolide content and thin-layer chromatography profiles of monarch butterflies, Danaus plexippus L., and their larval host-plant milkweed, Asclepias asperula subsp. capricornu (Woods.) Woods., in north central Texas. J. Chem. Ecol. 14, 295-318.

Martin, R. A., Lynch, S. P., Brower, L. P., Malcolm, S. B., and Van Hook, T. (1992). Cardenolide content, thin-layer chromatography profiles and emetic potency of monarch butterflies, Danaus plexippus, and their larval host-plant milkweed, Asclepias humistrata, in central Florida. Chemoecology 3, 1-13.

Missrie, M. (2004). "Design and implementation of a new protected area for overwintering monarch butterflies in Mexico," in The Monarch Butterfly. Biology and Conservation, eds K. S. Oberhauser, and M. J. Solensky (Ithaca, NY: Cornell University Press), 141-150.

Monarch Butterfly Fund (2018). Monarch Butterfly Fund: Conserving the Migration. Available online at: https://monarchconservation.org/ (accessed January 2, 2019).

Nelson, C. J., Seiber, J. N., and Brower, L. P. (1981). Seasonal and intraplant variation of cardenolide content in the California milkweed, Asclepias eriocarpa, and implications for plant defence. J. Chem. Ecol. 7, 981-1010.

Pasteur, G. (1982). A classificatory review of mimicry systems. Ann. Rev. Ecol. Syst. $13,169-199$.
Poulton, E. B. (1914). Mimicry in North American butterflies: a reply. Proc. Acad. Nat. Sci. Philad. 66, 161-195.

Pyle, R. M. (2019). Lincoln Brower's legacy of conservation. News Lepid. Soc. 60, 116-118. Available online at: http://images.peabody.yale.edu/lepsoc/nls/ 2010s/2018/2018_v60_n3.pdf

Seiber, J. N., Brower, L. P., Lee, S. M., McChesney, M. M., Cheung, H. T. A., Nelson, C. J., et al. (1986). Cardenolide connection between overwintering monarch butterflies from Mexico and their larval food plant, Asclepias syriaca. J. Chem. Ecol. 12, 1157-1170.

Urquhart, F. A. (1976). Found at last-monarchs winter home. Natl. Geogr. $150,161-173$.

Williams, E. H., and Brower, L. P. (2015). "Microclimatic protection of overwintering monarchs provided by Mexico's high-elevation oyamel fir forests: a review," in Monarchs in a Changing World: Biology and Conservation of an Iconic Butterfly, eds K. S. Oberhauser, K. R. Nail, and S. Altizer (Ithaca, NY: Cornell University Press), 109-116.

Zalucki, M. P., and Brower, L. P. (1992). Survival of first instar larvae of Danaus plexippus (Lepidoptera: Danainae) in relation to cardiac glycoside and latex content of Asclepias humistrata (Asclepiadaceae). Chemoecology 3, 81-93.

Zalucki, M. P., Brower, L. P., and Alonso-M, A. (2001a). Detrimental effects of latex and cardiac glycosides on survival and growth of first-instar monarch butterfly larvae Danaus plexippus feeding on the sandhill milkweed Asclepias humistrata. Ecol. Entomol. 26, 212-224.

Zalucki, M. P., Brower, L. P., and Malcolm, S. B. (1990). Oviposition by Danaus plexippus in relation to cardenolide content of three Asclepias species in the southeastern USA. Ecol. Entomol. 15, 231-240.

Zalucki, M. P., and Malcolm, S. B. (1999). Plant latex and first instar monarch larval growth and survival on three North American milkweed species. J. Chem. Ecol. 25,1827-1842.

Zalucki, M. P., Malcolm, S. B., Paine, T. D., Hanlon, C. C., Brower, L. P., and Clarke, A. R. (2001b). It's the first bites that count: survival of first-instar monarchs on milkweeds. Austral Ecol. 26, 547-555.

Conflict of Interest Statement: The authors declare that the research was conducted in the absence of any commercial or financial relationships that could be construed as a potential conflict of interest.

Copyright (c) 2019 Oberhauser, Alonso, Malcolm, Williams and Zalucki. This is an open-access article distributed under the terms of the Creative Commons Attribution License (CC BY). The use, distribution or reproduction in other forums is permitted, provided the original author(s) and the copyright owner(s) are credited and that the original publication in this journal is cited, in accordance with accepted academic practice. No use, distribution or reproduction is permitted which does not comply with these terms. 